Research Article

\title{
Gynecology Cancer in Relationship with Obesity
}

\author{
Hubungan Kanker Ginekologi dengan Obesitas
}

\author{
Gracia M R G Rauw, Bismarck J Laihad, Biran Affandi \\ Department of Obstetrics and Gynecology \\ Faculty of Medicine University of Sam Ratulangi/ \\ Prof. Dr. R. D. Kandou \\ Manado
}

\begin{abstract}
Objective: To know the relationship between obesity and gynecology cancer.

Method: This study use case control study design for 250 gynecology patients (125 controls and 125 cases) in Prof. Dr. R. D. Kandou Manado Hospital from 1 July to 30 November 2015. The data was collected by measuring Body Mass Index (BMI) and filing out selfadministered questioners.
\end{abstract}

Result: From the 250 subjects, the study group (125 subjects), 72 subjects have obesity $(57.6 \%)$ and 97 subjects have multiple parities $(77.6 \%)$ with 58 subjects diagnosed with cervical cancer (46.4\%). In the control group (125 subjects), 71 subjects have normal weight (56.8\%) and 67 subjects have multiple parities (53.6\%) with 64 subjects diagnosed with ovarium cysts (51.2\%). Using multivariate logistic regression, the overweight and obese subjects have 7 folds higher risk to develop gynecology cancer compared to those with normal or underweight subjects. Those with multiple parities and grande multipara subjects have 3 folds higher risk to develop gynecology cancer compared with those who are nullipara and primipara.

Conclusion: A significant correlation is found between obesity and gynecology cancer using multivariate logistic regression analysis $(\mathrm{p}=0.000,0 \mathrm{OR}=6.9$ (95\% CI = 3.62-13.13).

[Indones J Obstet Gynecol 2016; 1: 23-30]

Keywords: gynecology cancer, multiple parities, obesity

\begin{abstract}
Abstrak
Tujuan: Untuk mengetahui adanya hubungan obesitas dengan kanker ginekologi.

Metode: Penelitian ini menggunakan desain penelitian case control pada 250 pasien ginekologi (125 pasien kontrol dan 125 pasien kasus) di RSUP Prof. Dr. R. D. Kandou Manado dari tanggal 1 Juli 2015-30 November 2015. Pengumpulan data dilakukan dengan mengukur Indeks Massa Tubuh (IMT) dan mengisi kuesioner secara mandiri.

Hasil: Dari 250 pasien yang mengikuti penelitian, pada kelompok kasus (125 orang) didapatkan IMT obesitas sebanyak 72 orang $(57,6 \%)$, serta multiparitas sebanyak 97 orang $(77,6 \%)$ dengan diagnosis terbanyak kanker serviks 58 orang $(46,4 \%)$. Sedangkan pada kelompok kontrol (125 orang) didapatkan IMT ideal sebanyak 71 orang $(56,8 \%)$, serta multiparitas sebanyak 67 orang (53,6\%), dengan diagnosis terbanyak kista ovarium 64 orang $(51,2 \%)$. Berdasarkan analisis statistk regresi logistik multivariat, kelompok yang tergolong berat badan lebih dan obesitas mempunyai risiko hampir 7 kali menderita kanker ginekologik daripada yang kategori IMT-nya sangat kurus dan ideal. Pada pasien dengan riwayat multipara dan grande multipara mempunyai risiko 3 kali lipat lebih banyak menderita kanker ginekologi daripada pasien dengan riwayat nulipara dan primipara.
\end{abstract}

Kesimpulan: Setelah dilakukan analisis statistik regresi logistik multivariat ( $p=0,000 ; O R=6,90(95 \% C I=3,62-13,13)$ didapatkan $h u-$ bungan yang bermakna antara obesitas dengan kanker ginekologi.

[Maj Obstet Ginekol Indones 2016; 1: 23-30]

Kata kunci: kanker ginekologi, multiparitas, obesitas

Correspondence. Gracia MRG Rauw. Email: graciarauw@gmail.com

\section{INTRODUCTION}

The population structure is greatly changed due to the advancement in the science and technology of medical world and financial capacity. Along with the sophistication, the pathogenic pattern from infectious disease and malnutrition becoming more non-infectious and lifestyle associated ailments. This condition is concurred with the Transition Epidemiology Theory introduced by Omran in 1971. ${ }^{1}$ Several countries in the world or areas in one country may be in different level of transition. Health condition and disease characteristics are associated with financial growth and social structure in the society. Industrialism is the cause of mortality and morbidity dominated by chronic diseases such as cardiovascular disease, cancer, diabetes and obesity. ${ }^{1}$ Currently obesity is a global epidemic and is showing a more prominent impact. The prevalence of obesity in developing countries has increased 3 folds according to the World Health Organization. ${ }^{2,3}$ Obesity has become one of ten health problems in the world and top 5 in developing countries. Obesity in adult prevalence in the world reached 400 millions in 2005 and in 2015 it is predicted that will increased to 700 millions. ${ }^{3}$ In the developing countries, obesity is shown in a high frequency. Data from the WHO in 2008 the preva- 
lence of obesity in Indonesian adult is $9.4 \%$ with $2.5 \%$ men and $6.9 \%$ women proportionately. ${ }^{1}$ Previous survey in 2000 shown that only $4.7 \%$ Indonesian have obesity (approximately 9.8 million population). ${ }^{2}$ In a short span of 8 years the prevalence increases two folds. We need to be aware of the increasing rate because life style changes to a more sedentary and relaxed fashion as a result of technology advancement. ${ }^{2,3}$ Obesity is a manifestation of overweight meaning there are an abundant excess of fat in the body. Obesity differs from overweight in the weight difference. While overweight may possibly is caused by muscle or bone mass, or excess water (like in body builders). However, those two words (obesity and overweight) both signified a more than normal weight based on height. ${ }^{1}$

The criteria for obesity are based on Body Mass Index (BMI). BMI is a comparison between weight and height. The measurement is as follow: weight $(\mathrm{kg}) /$ (height $(\mathrm{m}) \mathrm{x}$ height $(\mathrm{m}) .^{1,2}$ If not addressed properly, obesity may have serious impact on health. Several studies show that obesity is tightly linked with several risk factors for degenerative diseases such as type II diabetes mellitus, hypertension, dyslipidemia, heart problem and even cancer. $^{1}$

Obesity is associated with an increased risk for several types of cancer. Malignancy caused by obesity is varied widely but $40 \%$ of the highest are endometrium cancer and esophageal adenocarcinoma. In the long run, obesity problem will continue to flourish and in 2030 will add 500,000 new cases in the United States. This analysis also found that if every adult cut off 1 point of their BMI, equivalent to $1 \mathrm{~kg}$ average adult weight, then it will prevent the increase by 100,000 less cases. ${ }^{4,5}$

Several mechanisms may be responsible in the association between obesity and the increased risk of cancer: fat tissue produces excess estrogen and a high level of estrogen is associated with increased risk of breast cancer, endometrium cancer and several other cancers. Obese individual usually has an increased of insulin and insulin-like growth factor-1 (IGF-1) in their blood stream (this condition is known for hyperinsulinemia or insulin resistance syndrome) which cause the development of several tumors. Fat cells produced hormones called adipokines which stimulates or inhibits cell growth. For example, Leptin which was found in abundance in obese individual can encourage cell proliferation and lesser level of adiponectin in obese individual may have anti-proliferative effect. Fatty cells also play a role in the regulation of other tumor cells growth. Obese individual often has subacute inflammation associated with an increased risk of malignancy. ${ }^{6}$ Other mechanisms such as the alteration of immune response, radiation exposure and oxidative stress. ${ }^{1,3,4}$ Cancer is still the second highest cause of death in developed countries after heart disease. In the United States, most often found cancer type in women is breast cancer followed by lung, colorectal and endometrium cancer. The highest mortality rate is caused by lung cancer followed by breast, colon, ovarium and pancreas. By evaluating the relationship between obesity and malignancy, Bergstrom evaluate the impact of obesity in cancer for European and concluded that 36,000 cases can be avoided annually by deplete the overweight and obese prevalence by $50 \%$. Calle also found that more than 90,000 deaths annually can be avoided by Americans if their adult BMI maintained at $<25 \mathrm{~kg} / \mathrm{m}^{2}$. Additionally, the increase of BMI also related to the increase of mortality in breast, uterus, cervix and ovarium cancer. For example, women with the most weight cohort (BMI $\geq 40 \mathrm{~kg} / \mathrm{m}^{2}$ ) have $62 \%$ death rate for cancer compared to women with normal weight. The increase of death rate for obese women with cancer showed an increased malignancy incidence in obese women compared to lean women. The prognosis for obese women with cancer is uncomely. Up until now many data are unreliable but suggestively leading to a conclusion signifying the close relationship between obesity and malignancy such as endometrium, cervix, breast in post menopause women, ovarium, colon and gall bladder. ${ }^{5}$

\section{METHODS}

This study used cross sectional case control study design for 250 gynecology patients in Prof. Dr. R. D. Kandou Manado Hospital from 1 July to 30 November 2015. The data collected by using BMI measurement and self-administered questioner.

Sampling criteria for the study groups are: patients coming to Prof. Dr. R. D. Kandou Hospital, diagnosed with gynecology cancer, obese and nonobese and willing to be respondents. Sampling criteria for control groups are: patients coming to Prof. Dr. R. D. Kandou Hospital, diagnosed with gynecology disease but not malignant, obese and non-obese and willing to be respondents. 


\section{RESULTS}

This study is a case control study by measuring subjects' BMI and analyzing questioners filled out by the subjects who came to Prof. Dr. R. D. Kandou
Manado Hospital. Study group is consist of $125 \mathrm{fe}-$ male subjects with gynecology cancer and control group is consists of 125 female subjects with nongynecology cancer.

Table 1. Subjects Characteristic Distribution

\begin{tabular}{|c|c|c|c|}
\hline & & (n) & $(\%)$ \\
\hline \multirow[t]{3}{*}{ Women Subject Status } & Cases & 125 & 50 \\
\hline & Control & 125 & 50 \\
\hline & Total & 250 & 100 \\
\hline \multirow[t]{6}{*}{ Age } & $\leq 20$ & 8 & 3.2 \\
\hline & $21-30$ & 14 & 5.6 \\
\hline & $31-40$ & 47 & 18.8 \\
\hline & $41-50$ & 101 & 40.4 \\
\hline & $>50$ & 80 & 32 \\
\hline & Total & 250 & 100 \\
\hline \multirow[t]{6}{*}{ Ethnic Group } & Minahasa & 169 & 67.6 \\
\hline & Mongondow & 24 & 9.6 \\
\hline & Gorontalo & 10 & 4 \\
\hline & Sangihe & 37 & 14.8 \\
\hline & Others & 10 & 4 \\
\hline & Total & 250 & 100 \\
\hline \multirow[t]{5}{*}{ BMI } & Underweight & 29 & 11.6 \\
\hline & Normoweight & 101 & 40.4 \\
\hline & Overweight & 42 & 16.8 \\
\hline & Obesity & 78 & 31.2 \\
\hline & Total & 250 & 100 \\
\hline \multirow[t]{6}{*}{ Occupation } & Housewives & 201 & 80.4 \\
\hline & Civil Clerk & 20 & 8 \\
\hline & Employee & 19 & 7.6 \\
\hline & Farmer/Fishwives & 3 & 1.2 \\
\hline & Others & 7 & 2.8 \\
\hline & Total & 250 & 100 \\
\hline \multirow[t]{5}{*}{ Education } & Primary School Graduate & 32 & 12.8 \\
\hline & Junior High School Graduate & 78 & 31.2 \\
\hline & High School Graduate & 110 & 44 \\
\hline & Undergraduate & 30 & 12 \\
\hline & Total & 250 & 100 \\
\hline \multirow[t]{3}{*}{ Marital Status } & Married & 236 & 94.4 \\
\hline & Single & 14 & 5.6 \\
\hline & Total & 250 & 100 \\
\hline
\end{tabular}




\begin{tabular}{llcc}
\hline Parities & $0-1$ & 86 & 34.4 \\
& $>1$ & 164 & 65.6 \\
Total & 250 & 100 \\
\hline Cervical Cancer & 58 & 23.2 \\
& Endometrium Cancer & 16 & 6.4 \\
& Ovarium Cancer & 51 & 20.4 \\
Mioma & 48 & 19.2 \\
& Endometriosis Cysts & 1.6 \\
& Ovarium Cysts & 4 & 25.6 \\
& Solid Ovarium Tumor & 64 & 3.6 \\
& Total & 9 & 100 \\
\hline \hline
\end{tabular}

In Table 1 we have the characteristics distribution of the 250 subjects willing to participate in this study. The age group of this study is 41-50 years old $40.4 \%$, Minahasa ethnic race $67.6 \%$ with normal BMI $40.4 \%$, high school graduate $44 \%$ and housewives $80.4 \%$. From the overall respondents $94.4 \%$ are married with multiple parities $65.6 \%$. The most common diagnosis from the subjects in our study is ovarium cysts $25.6 \%$.

Table 2. Characteristic Distribution in Study and Control Groups

\begin{tabular}{|c|c|c|c|c|}
\hline \multirow[t]{2}{*}{ Variable } & \multicolumn{2}{|c|}{ Cases } & \multicolumn{2}{|c|}{ Control } \\
\hline & $\mathbf{n}$ & $\%$ & $\mathbf{n}$ & $\%$ \\
\hline \multicolumn{5}{|l|}{ Age } \\
\hline$\leq 20$ & 0 & 0 & 8 & 6.4 \\
\hline $21-30$ & 5 & 4 & 9 & 7.2 \\
\hline $31-40$ & 23 & 18.4 & 24 & 19.2 \\
\hline $41-50$ & 50 & 40 & 51 & 40.8 \\
\hline$>50$ & 47 & 37.6 & 33 & 26.4 \\
\hline Total & 125 & 100 & 125 & 100 \\
\hline \multicolumn{5}{|l|}{ BMI } \\
\hline Underweight & 10 & 8 & 19 & 15.2 \\
\hline Normoweight & 30 & 24 & 71 & 56.8 \\
\hline Overweight & 13 & 10.4 & 29 & 23.2 \\
\hline Obesity & 72 & 57.6 & 6 & 4.8 \\
\hline Total & 125 & 100 & 125 & 100 \\
\hline \multicolumn{5}{|l|}{ Occupation } \\
\hline Housewives & 99 & 79.2 & 102 & 81.6 \\
\hline Civil Clerk & 10 & 8 & 10 & 8 \\
\hline Employee & 12 & 9.6 & 7 & 5.6 \\
\hline Farmer/Fishwives & 3 & 2.4 & 0 & 0 \\
\hline Others & 1 & 0.8 & 6 & 4.8 \\
\hline Total & 125 & 100 & 125 & 100 \\
\hline
\end{tabular}




\begin{tabular}{|c|c|c|c|c|}
\hline \multirow[t]{2}{*}{ Variable } & \multicolumn{2}{|c|}{ Cases } & \multicolumn{2}{|c|}{ Control } \\
\hline & $\mathbf{n}$ & $\%$ & $\mathbf{n}$ & $\%$ \\
\hline \multicolumn{5}{|l|}{ Education } \\
\hline Primary School Graduate & 19 & 15.2 & 13 & 10.4 \\
\hline Junior High School Graduate & 29 & 23.2 & 49 & 39.2 \\
\hline High School Graduate & 64 & 51.2 & 46 & 36.8 \\
\hline Undergraduate & 13 & 10.4 & 17 & 13.6 \\
\hline Total & 125 & 100 & 125 & 100 \\
\hline \multicolumn{5}{|l|}{ Parities } \\
\hline $0-1$ & 28 & 22.4 & 58 & 46.4 \\
\hline$>1$ & 97 & 77.6 & 67 & 53.6 \\
\hline Total & 125 & 100 & 125 & 100 \\
\hline \multicolumn{5}{|l|}{ Diagnosis } \\
\hline Cervical Cancer & 58 & 46.4 & 0 & 0 \\
\hline Endometrium Cancer & 16 & 12.8 & 0 & 0 \\
\hline Ovarium Cancer & 51 & 40.8 & 0 & 0 \\
\hline Mioma & 0 & 0 & 48 & 38.4 \\
\hline Endometriosis Cysts & 0 & 0 & 4 & 3.2 \\
\hline Ovarium Cysts & 0 & 0 & 64 & 51.2 \\
\hline Solid Ovarium Tumor & 0 & 0 & 9 & 7.2 \\
\hline Total & 125 & 100 & 125 & 100 \\
\hline \multirow[t]{2}{*}{ Variable } & \multicolumn{2}{|c|}{ Obese } & \multicolumn{2}{|c|}{ Non-Obese } \\
\hline & $\mathbf{n}$ & $\%$ & $\mathbf{n}$ & $\%$ \\
\hline \multicolumn{5}{|l|}{ Diagnosis } \\
\hline Cervical Cancer & 35 & 28 & 23 & 18.4 \\
\hline Endometrium Cancer & 14 & 11.2 & 2 & 1.6 \\
\hline Ovarium Cancer & 34 & 27.2 & 17 & 13.6 \\
\hline Total N Diagnosis & 125 & $100 \%$ & & \\
\hline \multirow[t]{2}{*}{ Variable } & \multicolumn{2}{|c|}{ Obese } & \multicolumn{2}{|c|}{ Non-Obese } \\
\hline & $\mathbf{n}$ & $\%$ & $\mathbf{n}$ & $\%$ \\
\hline \multicolumn{5}{|l|}{ Diagnosis } \\
\hline Mioma & 21 & 16.8 & 27 & 21.6 \\
\hline Endometriosis Cysts & 1 & 0.8 & 3 & 2.4 \\
\hline Ovarium Cysts & 12 & 9.6 & 52 & 41.6 \\
\hline Solid Ovarium Tumor & 0 & 0 & 9 & 7.2 \\
\hline Total N Diagnosis & 125 & $100 \%$ & & \\
\hline
\end{tabular}

Our study group shown in Table 2, 50 subjects $(40 \%)$ are in the age group between $31-50$ years old, 72 subjects with obesity BMI (57.6\%), high school graduate 64 subjects (51.2\%), housewives 99 subjects (79.2\%) with multiple parities 97 subjects $(77.6 \%)$ and diagnosed with cervical cancer 58 subjects (46.4\%). In the control group 51 subjects (40.8\%) are in the age group between $41-50$ years old, 71 subjects with normal weight BMI (56.8\%), junior high school graduate 49 subjects (39.2\%), housewives 102 subjects $(81.6 \%)$ with multiple parities 67 subjects (53.6\%) and diagnosed with ovarium cysts 64 subjects $(51.2 \%)$.

In the control group, from 48 subjects that are diagnosed with myoma utery, 21 subjects have 
obesity (16.8\%), from 4 subjects that are diagnosed with endometrium cysts, 1 subject has obesity $(0.8 \%)$, from 64 subjects diagnosed with ovarium cysts, 12 have obesity (9.6\%), from 9 subjects diagnosed with solid ovarium tumor, all of them have normal weight.

In the study group, from 58 subjects that are diagnosed with cervical cancer, 35 subjects have obesity (28\%), from 16 subjects with endometrium cancer, 14 subjects have obesity (11.2\%), from 51 subjects diagnosed with ovarium cancer, 34 subjects have obesity (27.2\%).

From those characteristics table above, we follow through with a logistic regression analysis test to address the happening of gynecology cancer with obesity, education, marital status, history of diabetic parities, gynecology malignancy history, non-gynecology malignancy history, vegetable dietary, fruit dietary, exercise, alcohol consumption history, smoking history and the use of contraception as the risk factors.

From the multivariate logistic regression analysis for those risk factors in the relationship to gynecology cancer, obesity and parities have significant relationship in the development of gynecology cancer; $\mathrm{p}=0.000, \mathrm{OR}=6.90(95 \% \mathrm{CI}=3.62$ 13.13), and $\mathrm{p}=0.004, \mathrm{OR}=2.95(95 \% \mathrm{CI}=1.41-$ 6.19), respectively.

Those who are overweight and obese have a risk of 7 folds higher than those with normal weight to have gynecology malignancy. Those who have multiple and grand multiple parities have 3 folds higher risk to develop gynecology cancer compared to the nullipara and primipara.

\section{DISCUSSION}

This study was conducted in Prof. Dr. R. D. Kandou Manado Hospital since July to November 2015. The subjects are 125 women with gynecology cancer and 125 women with non-gynecology cancer. All study subjects have fulfilled the inclusion and exclusion criteria and signed the consent form to participate in this study. This study is done with 2 steps; fill out the questioners and physical examination.

Cancer is still the second highest cause of death in developed countries after heart disease. Obesity is related to the increase risk for several types of cancer. The rate of cancer caused by obesity varied largely, but $40 \%$ is endometrium cancer and esophageal adenocarcinoma. The increase of BMI also related to the increase of mortality in breast, uterus, cervical and ovarium cancer. For example, women from the heaviest weight cohort (BMI $>40$ $\mathrm{kg} / \mathrm{m}^{2}$ ) have a death rate for cancer $62 \%$ higher than women with normal weight. The increase of death rate for obese women with cancer showed that the increase of cancer incidence in obese women has worse prognosis than those with normal weight. There is an analysis that showed if an adult decrease 1 point of their BMI, equivalent to $1 \mathrm{~kg}$ of adult average weight, then the increase of incidence will be avoided.

The subjects in this study are patients of Prof. Dr. R. D. Kandou Manado Hospital. There are 125 women in the study group with 50 subjects in the age group of 41-50 years old (40\%), 72 subjects with obesity BMI (57.6\%), high school graduate 64 subjects $(51.2 \%)$, housewives 99 subjects $(79.2 \%)$ and diagnosed with cervical cancer 58 subjects (46.4\%). In the control group we have 125 subjects with 51 subjects in the age group of 41-50 years old $(40.8 \%)$, normal weight BMI 71 subjects (56.8\%), junior high school graduate 49 subjects (39.2\%), housewives 102 subjects (81.6\%), and diagnosed with ovarium cysts 64 subjects (51.2\%).

We measure the relationship significance of obesity in the development of gynecology cancer in the patients of Prof. Dr. R. D. Kandou Manado Hospital. Obesity is defined with BMI $>30 \mathrm{~kg} / \mathrm{m}^{2}$.

Obesity is related to the increase of malignancy risk in gynecology by several pathways. Mechanisms such as insulin resistance, adipokine, sex steroid, inflammation and genetic polymorphism may play a role in the development. A holistic understanding of obesity relationship to gynecology cancer may help avoid malignancy from happening and provide a better prognosis.

In this study we use multivariate logistic regression analysis to see the relationship between risk factors and gynecology cancer. We found that obesity $(\mathrm{p}=0.000, \mathrm{OR}=6.90(95 \% \mathrm{CI}=3.62-13.13))$. Those who are overweight and obese have 7 times higher risk for gynecology malignancy than those with normal or underweighted.

This finding supports previous results which evaluate the role of obesity in cancer incidence. Bergstrom looked into the role of obesity in European cancer and found that by decreasing the 
prevalence of overweight and obese patients by $50 \%$ there will be 36,000 less cancer cases annually. Calle also found that more 90,000 deaths can be avoided yearly in the United States if every adult can maintain their BMI to less than $25 \mathrm{~kg} / \mathrm{m}^{2}$. Additionally the increase of BMI also related to the increase of death rate in breast, uterus, cervical and ovarium cancer patients. For instance, women from the heaviest weight cohort (BMI $>40 \mathrm{~kg} / \mathrm{m}^{2}$ ) have $62 \%$ higher death rate than women with normal weight. The increase in obese women with cancer showed an increase in cancer incidence in obese women compared to lean women and the outcome for obese women is significantly worse. Lahmann also found other risk factors for epithelial type ovarium cancer: BMI. A study found that women with $>30 \mathrm{~kg} / \mathrm{m}^{2}$ BMI (obesity) have 1.59 relative higher risk to develop ovarium cancer compared to those with normal BMI. 3,5

In a study in the United States it was found that the increase of BMI and waist measurement is one of the risk factors related to endometrium cancer but it is still unknown whether those factors are determinant for the prognosis. Specifically, women obesity (BMI $>30 \mathrm{~kg} / \mathrm{m}^{2}$ ) increase the risk of endometrium cancer by $76 \%$ and women with > 0.8530 waist measurement increase the risk of endometrium cancer by $33 \%$. Freidenreich et al found that women with $30-40 \mathrm{~kg} / \mathrm{m}^{2}$ BMI have 1.78 more risk for endometrium cancer than women with normal BMI. Menopause women with obesity produce more estrogen than necessary. It is owed to the peripheral conversion in the adipose tissue from androgen secreted by adrenal gland and ovarium to estrone by aromatase. Long term exposure to uninhibited estrogen will cause changes in some spectrum of endometrium proliferation such as hyperplasia of endometrium/polyp to endometrium cancer.

The relationship between obesity and ovarium cancer is still unknown. Several studies suggest an existence of relation. But several other contradict the notion. Endogen hormone is believed to be one of the causes of ovarium cancer but the conclusion for the role of obesity in ovarium malignancy is still undecided.

In a study by Ovarian Cancer Association Consortium it is found that obesity may increase the risk of ovarium cancer with borderline histology subtype and low grade invasive type. ${ }^{7}$

There is still a lack of study in regard of the relationship between BMI and cervical cancer. In one study, an increased risk in women with excess body weight and obese to cervical cancer especially cervical adenocarcinoma and cervical squamous cell carcinoma is found but in a low significance. ${ }^{8}$ It is seemed that this is due to the decrease of body immunity in those with obesity whereas one of the several causes of cervical cancer is Human Papilloma Virus infection. ${ }^{9}$

Based on the multivariate logistic regression statistical analysis of the risk factors related to gynecology cancer, we found that obesity and parities (p $=0.004, \mathrm{OR}=2.95(95 \% \mathrm{CI}=1.41-6.19)$ ) have significant result. Those with multiple pregnancies and grandemultipara have 3 folds higher risk to gynecology cancer than those with nullipara and primipara. This result support other previous results.

The initial result was delivered by Rigoni-Stern. In 1842, Rigoni-Stern published an analysis of death caused by cancer by the number of incidence in Verona from 1760 to 1839 . They found that married women and widows may develop cervical cancer but the occurance is rare in unmarried women and nuns. They concluded that certain functional changes in the utery are related to pregnancy or delivery which causes the predisposition for cervical cancer. This carcinogenesis theory is supported by Broussais study who previously speculated that there might be a relationship between chronic irritation or trauma to neoplasm. Cervical continuous laceration, abration and infection related to indecent obstetric care or multiple parities may act as a causing factor. This finding is explained by Weinberg and Gastpar several years later that women from lower financial strata has higher risk for cervical cancer. Peluchi also study the relationship of multiple parities and the decrease of ovarium cancer risk where those with multiple parities have 0.60.8 more risk relatively to ovarium cancer than nullipara. ${ }^{10-12}$

\section{CONCLUSION}

We found significant result in the statistical analysis for the relationship of obesity and gynecology cancer. Those who are overweight and obese have 7 folds higher risk for gynecology cancer than those with normal and underweight. In obese grandemultipara the number of gynecology cancer incidence is higher than nullipara. Those multipara and grandemultipara have 3 folds higher risk for gynecology cancer than those who are nullipara and primipara. 


\section{REFERENCES}

1. Affandi B, Gunardi ER, Santoso BI. Kesehatan Reproduksi dan Obesitas. Divisi Kesehatan Reproduksi Departemen Obgin FKUI. 2014.

2. Gustafsson F, Kragelund CB, Torp-Pederson C et al. Effect of Obesity and Overweight on Long Term Mortality in Congestive Heart Failure, Influence Of Left Ventricular Systolic Function, Eur Heart J. 2006; 26: 58-64.

3. WHO, Obesity: Preventing and Managing The Global Epidemic: Report of a WHO Consultation. Technical Report Series. Geneva, Switzerland. 2000: 894.

4. Hariadi dan Ali, Arsad Rahim. 2005. Hubungan Obesitas dengan Beberapa Faktor Risiko Penyakit Jantung Koroner di Laboratorium Klinik Prodia Makassar Tahun 2005. http://arali2008.files.wordpress.com/2008/09/obesitasdan-jantung-koroner.pdf

5. Pamela, Dyah R. Overweight dan Obesitas sebagai Suatu Risiko Penyakit Degeneratif. 2011.http://www.suyotohospital.com/index.php?option=com_content\&view=article\&id =115:overweight-dan-obesitas-sebagai-suatu-risiko-penya kit degeneratif\&catid=3: artikel\&Itemid $=2$

6. Vvan Kruijisdjiik RC, van der Wall E, Visseren FL. Obesity and cancer the role of dysfuctional adipose tissue. Cancer epidemiology, biomarkers and prevention: a publication of the American Association for Cancer Research, cosponsored by t Am Soc Prev Oncol. 2009: 2569-78.

7. Calle EE, Kaaks R. Overweight, obesity and cancer: Epidemiological evidence and proposed mechanisms. Nat Reviews Cancer. 2004: 579-91.

8. Wadpadji S. Naskah Lengkap Pertemuan Ilmiah Tahunan Ilmu Penyakit Dalam Jakarta: Pusat Informasi dan Penerbitan Departemen Ilmu Penyakit Dalam FK UI, 2004: 79-89.

9. Tjandraningrum. Pengaruh Diet rendah Kalori Seimbang Indeks Glikemik Rendah dan Tinggi Terhadap Berat Badan, Lingkar Pinggang dan komposisi Tubuh Perempuan Obese. Tesis. Program Studi Ilmu Gizi Kekhususan Gizi Klinik Program Pendidikan, Pasca Sarjana FK UI. Jakarta: 2008.

10. Vucenik I, Stains JP. Obesity and cancer risk: evidence, mechanisms and recommendations. Annal of the New York Academy of Sciences 2012: 37-43.

11. Marti A, Marcos A, Martinez JA. Obesity and immune function relationships. Obesity reviews: an official J Int Associat Study Obes 2001: 131-40.

12. Copeland J Larry. Premalignant Lesions of the Cervix. In: Text book of Gynecology. Philadelphia: WB Saunders Company. 2000: 1225-56 